\title{
From Toyota Production System to Lean Retailing. Lessons from Seven-Eleven Japan
}

\author{
Shinji Naruo ${ }^{1}$ and Sorin George Toma ${ }^{2}$ \\ 1 University of Bucharest, Faculty of Business and Administration, \\ University from Bucharest, 36-46 Bd. M. Kogalniceanu, Bucharest \\ 050107, shinjinaruo@ yahoo co.jp, \\ WWW home page: http://Www.unibuc.ro \\ 2 Academy of Economic Studies, Faculty of Commerce \\ 13-15 M. Eminescu, Bucharest 010511, Romania \\ tomagsorin@yahoo.com, \\ WWW home page: http://www.ase.ro
}

\begin{abstract}
In order to face their global competitors, one solution consists for manufacturing companies around the world to implement the Toyota Production System (TPS). Lean manufacturing evolved from TPS. The purpose of the paper is to demonstrate that lean principles and concepts can be successfully applied in a company from the retail industry, such as Seven-Eleven Japan. Lean retailing is now a reality that has forced manufacturers to build standard products ondemand using build-to-order techniques. The retail markets are characterized by a strong competition, short product life cycles, long product development lead times, and highly volatile demand. Today's powerful retailers insist on low prices and refuse to carry inventory. The main objectives of the paper were achieved by using an extensive review of the literature and a case study.
\end{abstract}

\section{Keywords}

Toyota Production System (TPS), lean, manufacturing, retailing, Seven-Eleven Japan

\section{Introduction}

The automobile was introduced more than one hundred years ago. The automotive age began in Europe at the end of the $19^{\text {th }}$ century when C. Benz started the first commercial production of motor vehicles in 1886, and when twenty-three 
automobiles participated in a race from Versailles to Bordeaux and back to Paris in 1895 [2].

At the beginning of the $20^{\text {th }}$ century, it was clear for everyone that the automobile represented modernity and progress. The Ford Motor Company was founded in Detroit in 1903. When H. Ford launched the famous Model $\mathrm{T}$ in 1908, he understood that a big business was born. All his plants and branches around the world assembled and sold the Model $\mathrm{T}$, following the assembly line method developed by Ford at Detroit. Based on mass production and economies of scale, the Fordian model implemented a "volume" strategy, accompanied by an advertised brand name. Ford Motor became the epitome of the modern multinational company and the term "Fordism" symbolized the new corporate America. At the end of 1920's, Ford was overtaken by General Motors and then by Chrysler. Created to break away from preceding models, the Sloanist model applied a "volume and diversity" strategy.

\section{From Fordism to toyotism}

Later, adapting Fordism selectively, the Japanese developed flexible production systems. By using quality circles, team output, or pull systems, they transformed Fordism into Toyotism. The Toyota Production System (TPS) evolved from the Ford manufacturing system. The primary purpose of TPS is to obtain profit through cost reduction, or productivity improvement [6]. Cost reduction and productivity improvement are attained through the elimination of different kinds of waste, such as excessive inventory. The basis of the TPS is the absolute elimination of waste [7].

Today, TPS represents not only tools, methods and techniques, but also a way of doing business. The two pillars of the so-called "Toyota Way" are continuous improvement and respect for people. The principles that constitute the Toyota Way are related to a long term business philosophy. Based on his 20 years of studying the Toyota Company, Liker stated that 14 main principles constitute the so-called "Toyota Way" [1]. These principles represent the foundation of TPS and are divided into the following 4 categories (the 4 "P" model): philosophy (long-term thinking), process (eliminate waste), people and partners (respect, challenge, and grow them), and problem solving (continuous improvement and learning).

Among other elements, the kanban system is a key of TPS. This system is supported by smoothing of production, standardization of jobs, autonomation, and improvement activities [6].

In 2003, Toyota overtook Ford Motor to become the second largest automaker of the world. In the first quarter of 2007, Toyota unseated GM as the world's largest automaker.

Businesses today have struggled to successfully imitate Toyota. That is why other Japanese companies are trying to implement TPS in their plants (box 1). 
Table 1. The principles of Toyota Way

\begin{tabular}{|c|c|}
\hline Section & Principle \\
\hline $\begin{array}{l}\text { I. Long-Term } \\
\text { Philosophy }\end{array}$ & $\begin{array}{l}\text { 1. Base your management decisions on a long-term philosophy, even at } \\
\text { the expense of short-term financial goals }\end{array}$ \\
\hline \multirow{7}{*}{$\begin{array}{l}\text { II. The Right } \\
\text { Process Will } \\
\text { Produce the } \\
\text { Right Results }\end{array}$} & 2. Create continuous process flow to bring problems to the surface. \\
\hline & 3. Use "pull" systems to avoid overproduction. \\
\hline & 4. Level out the workload (heijunka). \\
\hline & $\begin{array}{l}\text { 5. Build a culture of stopping to fix the problem, to get quality right the } \\
\text { first time. }\end{array}$ \\
\hline & $\begin{array}{l}\text { 6. Standardized tasks are the foundation for continuous improvement and } \\
\text { employee empowerment. }\end{array}$ \\
\hline & 7. Use visual control so no $p$ \\
\hline & able, thoroughly tested technology that serves your people \\
\hline \multirow{3}{*}{$\begin{array}{l}\text { III. Add Value } \\
\text { to the } \\
\text { Organization by } \\
\text { Developing } \\
\text { Your People and } \\
\text { Partners }\end{array}$} & $\begin{array}{l}\text { 9. Grow leaders who thoroughly understand the work, live the philosophy, } \\
\text { and teach it to others. }\end{array}$ \\
\hline & $\begin{array}{l}\text { 10. Develop exceptional people and teams who follow your company's } \\
\text { philosophy. }\end{array}$ \\
\hline & $\begin{array}{l}\text { 11. Respect your extended network of partners and suppliers by } \\
\text { challenging them and helping them improve. }\end{array}$ \\
\hline \multirow{3}{*}{$\begin{array}{l}\text { IV. } \\
\text { Continuously } \\
\text { Solving Root } \\
\text { Problems Drives } \\
\text { Organizational } \\
\text { Learning }\end{array}$} & $\begin{array}{l}\text { 12. Go and see for yourself to thoroughly understand the situation (genchi } \\
\text { genbutsu). }\end{array}$ \\
\hline & $\begin{array}{l}\text { 13. Make decisions slowly by consensus, thoroughly considering all } \\
\text { options implement decisions rapidly. }\end{array}$ \\
\hline & $\begin{array}{l}\text { 14. Become a learning organization through relentless reflection (hansei) } \\
\text { and continuous improvement (kaizen). }\end{array}$ \\
\hline
\end{tabular}

\section{Box 1- Introduction of TPS at Fujitsu Component Limited}

In May 2001, Fujitsu Component Limited, one of the companies of the Japanese Fujitsu Group, was selected to put TPS into practice [9]. In order to improve its performances, outside TPS consultants were hired. In approximately 15 months, major improvements occurred as follows:

- Three-fold increase in productivity;

- $50 \%$ reduction in inventories;

- $50 \%$ reduction of work space;

- $48 \%$ reduction in manufacturing lead time.

The successfully introduction of TPS in Fujitsu Component Limited was enabled by:

- A revolution in employees consciousness;

- A sense of crisis felt by all employees and management;

- Producing what is needed in only the required quantity when it is needed (the pull production system);

- Searching solutions for the complete elimination of waste.

In sum, the introduction of TPS comprised two main stages:

1. Instruction activities and elimination of waste activities;

2. Full-scale TPS principles implementation. 


\section{TPS and lean manufacturing}

Lean means a systematic approach to identifying and eliminating "muda" (waste) through continuous improvement. It seems that the famous Henry Ford had been using parts of lean as early as the 1920's. But, the TPS was the fundamental basis for the "lean" movement that has dominated manufacturing environments for the last fifteen years (box 2).

Box 2- Applying lean manufacturing at Toyota plant at Georgetown (USA)

In 2006, the 7.5 million square foot Toyota factory located in Georgetown produced more than a half million vehicles [4]. The Georgetown plant is the biggest Toyota Motor's manufacturing facility in North America. Using pull system, andon, kanban and other TPS tools, Toyota Motor Manufacturing Kentucky (TMMK) is designed to produce vehicles in a continuous flow. As S. St. Angelo, the president of TMMK, stated, "there were a great difference between GM's mass production and the TPS" and "more car manufacturers are going towards what is called lean manufacturing, which is just another flavour of TPS". Its entire culture was built around the lean philosophy, based on waste elimination and on the continuous improvement of its manufacturing and business processes. Producing best quality cars, with fewer worker-hours, lower inventory and fewer defects, than any other competitor in the world, this lean factory is using technology on a large scale. In this respect, Toyota formed at the end of the 1990's a partnership with ABB Automation Technology, a Swiss- based maker of manufacturing robots. Due to the painting robots, Toyota saves about 29 USD per vehicle, and 2.1 hours off the time needed to produce a vehicle.

Step by step, the lean movement has penetrated other industries, like retailing. Lean retailing is now a reality that has forced manufacturers to build standard products ondemand using build-to-order techniques. The retail markets are characterized by a strong competition, short product life cycles, long product development lead times, and highly volatile demand.

Today's powerful retailers insist on low prices and refuse to carry inventory. That is why lean retailers are now expecting manufacturers to provide rapid and frequent replenishment of retail goods based on real-time sales. In other words, manufacturers are now facing lean retailing pressures. Lean retailing itself contributes to the transformation of manufacturing.

Lean gives Seven-Eleven Japan the clear vision to see what markets desire. Also, lean retailing provides competitiveness for this largest convenience store chain in Japan.

\section{Expanding lean in the retailing industry. Study case: Seven Eleven Japan}

We can compare the lean management structure between manufacture and retail industry. For example, the kanban system used in TPS imposes on the later process 
to send requests to the earlier one. It means that demand represents a trigger in the manufacturing industry. This concept is similar to Demand Chain Management (DCM) in retail industry.

If TPS has some key concepts like JIT, Kanban, or Autonomation, there are no established lean management concepts in retail, but there are other similar concepts like Supply Chain Management (SCM), DCM, franchise system, or in store merchandising. These concepts are not still organized as lean concepts in retail. However, when we have studied Seven-Eleven Japan (SEJ), we found similar corporate philosophy between Toyota and SEJ. They both trust human intelligence and they don't take automation easily. In case of Toyota, it is Autonomation, and in case of SEJ, it is individual store management. Both companies are excellent companies in their field. They have achieved high business performance, created unique corporate philosophy and global operation in the world.

Table 2. Comparison between manufacturing and retail regarding lean management

\begin{tabular}{|c|c|c|c|}
\hline & \multicolumn{3}{|c|}{ Lean $m$ anagem ent } \\
\hline & Manufactaring & \multicolumn{2}{|c|}{ Retailing } \\
\hline & TPS (Toyota Production System) & General model and concept & Seven-Eleven key concept \\
\hline & JT (Lst In Time) & SCM (Supply Chain Management) & $\mathrm{CDC}, \mathrm{NDF}$ \\
\hline 2 & Kanban system & DCM (Demand Chain Management) & Store initiative ordering \\
\hline 3 & Production smoothing & SCM (Supply Chain Management) & Team merchandising \\
\hline 4 & Shortening setup time & SCM (Supply Chain Management) & Customerfocus \\
\hline 5 & Shortened Lead Time & Order-delivery & Dominant strategy \\
\hline 6 & Standardization of Operations & Franchise system & Store initiative ordering \\
\hline & Autonomation & In store merchandising & Individual store managemen \\
\hline & Kaizen (Improvement Activities) & In store team meeting & Tanpinkanri \\
\hline
\end{tabular}

SEJ was opened in 1974 in Tokyo based upon international licensing agreement with Southland Corporation, USA (currently Seven-Eleven, Inc, USA). Now, SEJ operates 11,525 stores (as of December 2006) in Japan. The total store sales was $2,498,754$ millions yen $(\$ 21,275 \mathrm{mil})$ and the revenue from operations was 492,831 millions yen $(\$ 4,176$ mil) in Japan. SEJ achieves this huge profit with only 4,804 employees because of its franchise system.

$\mathrm{SEJ}$ is a franchiser of Seven-Eleven convenience stores in Japan. Each store has about 100-150 square meters sales floor and 2500 Stock Keeping Unit (SKU). Daily customer transaction in each store is about 1,000 and the average purchase amount is \$5-6 per customer. However, SEJ keeps growing on sales and in the number of stores in past 30 years. They believe that "Reviewing and changing day-to-day business from the standpoint of the customer is the basis for breakthroughs". It is "TANPINKANRI" (item by item control), the basis of retailing. SEJ is facing three main lean challenges.

Lean challenge no. 1: Total integration in the process from ordering to delivery Ordering in each store with store's responsibility is the key. Store employee orders each item in the store. The order goes to Data center. Data center analyzes the order data, and then generates order data to the vendor, picking data/shipping instruction to distribution center, and inspection data to each store. Based upon this integrated 
information flow, delivery process is well managed among store, vendor and distribution center. After store inspection, inspected data goes to accounting center. Accounting center verifies the data, and then sends account payable data to vendors. The whole process looks like a TPS line. Data, paper, product and human resources work together efficiently without waste (Fig. 1). The delivery route and schedule are also carefully designed in each store group. In order to improve the delivery network, SEJ conducts the strategic process.

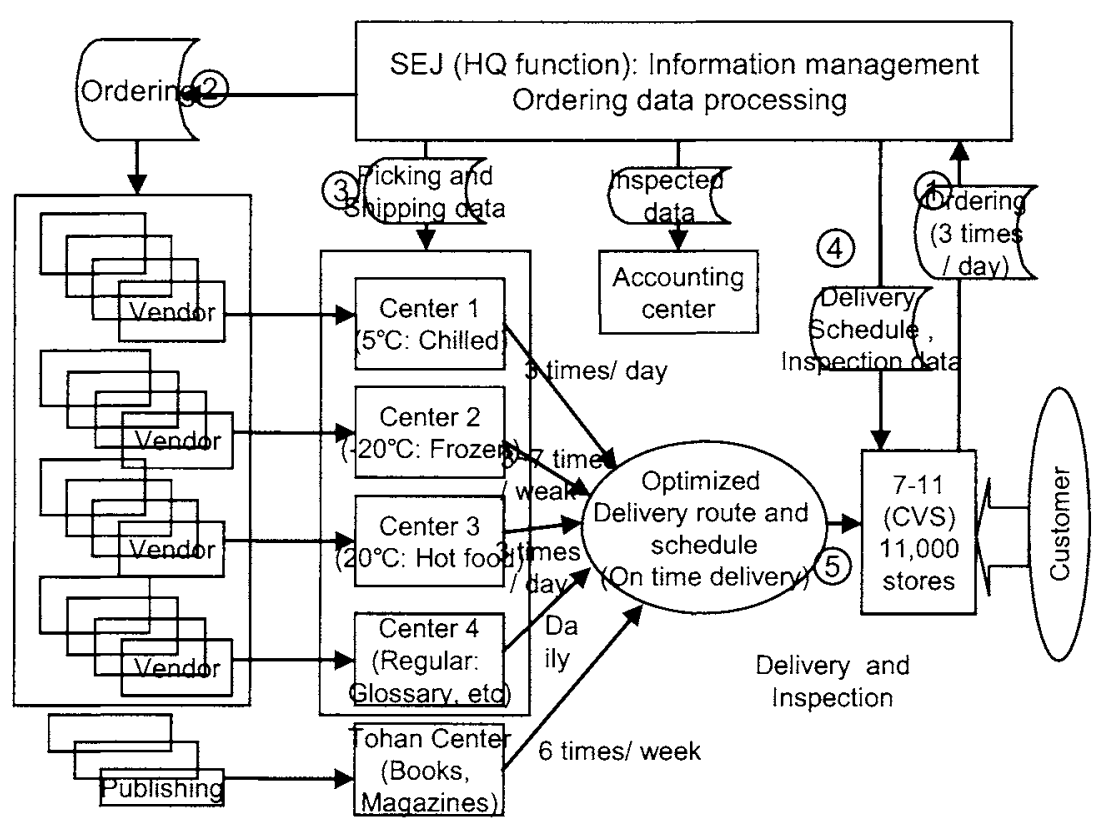

Fig. 1. Total integration system from ordering to delivery

Lean challenge no. 2: Increasing delivery frequency with reducing number of tracks In 1974, there were 70 times deliveries to stores per day per store in SEJ. Now, it is only 9 times deliveries per day per store (Fig. 2). This enabled drastic reduction of the distribution costs. Furthermore, it reduced inspection workload in store side. On the other hand, it enabled the store operators to concentrate on sales and customers in the store. SEJ had succeeded in increasing delivery frequency by product category. The SEJ success relies on the designing of a combined distribution center (CDC). SEJ designed the CDC concept by category and by temperature. CDC is operated by a vendor's representative, or by an independent third party (Table 3 ). 


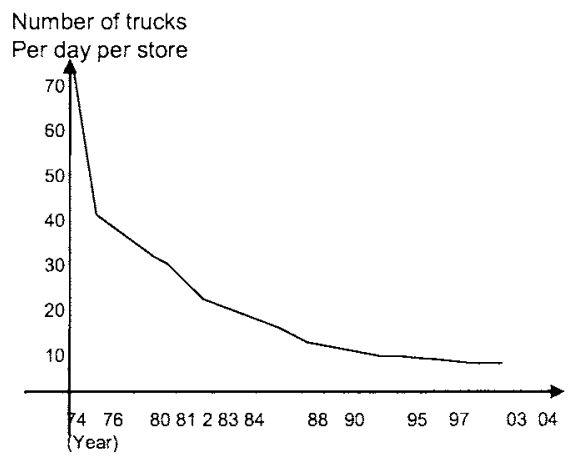

Fig. 2. Reduce number of trucks with increasing service level.

Table 3. CDC for integration distribution system

\begin{tabular}{|l|l|l|l|}
\hline \multicolumn{2}{|c|}{ Combined Distribution Center $(\mathrm{CDC})$} & Delivery frequency & Number of Centers \\
\hline $5:$ management & Chilled food Center & 3 times a day & 67 Centers \\
\hline $20:$ management & Hot food Center & 3 times a day & 69 centers \\
\hline 20 : management & Frozen center & $3-7$ per week & 47 centers \\
\hline Ambient temperature & $\begin{array}{l}\text { Focess food center } \\
\text { iquer center } \\
\text { Seneral goods Center } \\
\text { Sundries and Confectionery } \\
\text { Center }\end{array}$ & $\begin{array}{c}145 \text { centers } \\
\text { (naily delivery } \\
\text { ambient temperature } \\
\text { centers) }\end{array}$ \\
\hline
\end{tabular}

(Data from SEJcorporate outline 2005)

Lean challenge no. 3: Increase sales combined with decrease inventory.

It used to be wrong common sense in retail. For example, one was "much merchandise in store enables large sales". Many retailers believed in the common sense, but SEJ doubted. SEJ narrowed the number of SKU, and then reduced inventory level by deleting dead items. The results were a financial cost reduction and a store image change. Due to a lower inventory level, stores had the chance to introduce new items, and that attracted customers. The Japanese Seven-Eleven stores are a third of those in US, and that is why they are putting significant limits on inventory space at the store. During its existence, SEJ has proved the relationship between inventory and sales (Fig. 3).

This slim body approach of SEJ is similar to TPS inventory reduction. TPS reduces inventory, and then increases productivity and quality. TPS enables a better working environment, high performance and quality management. SEJ's store has achieved the same thing. Dead item eats space, and this is waste. By reducing SKU, space is creating, and this enable customers to walk and find easy the merchandises in the stores.

SEJ's corporate philosophy is "Corresponde to changes and execute basic principles thoroughly". Top management declares "Tomorrow is another day". In order to be agile in the market, SEJ must keep lean. In this respect, SEJ has implemented three strategies for keeping an agile constitution. 


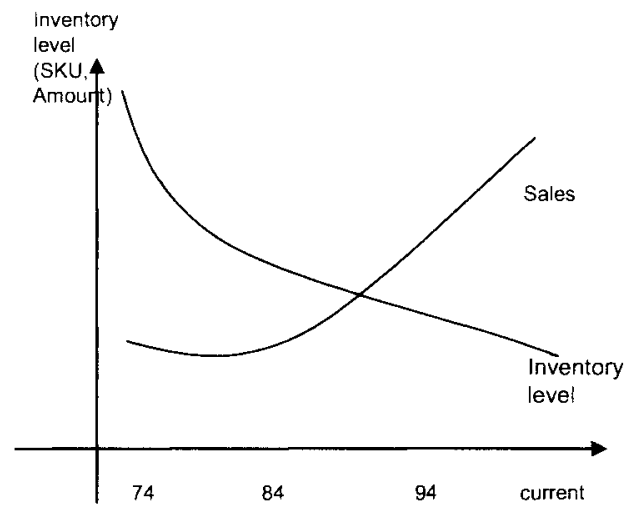

Fig. 3. Relation between inventory and sales

The first strategy is the the franchise system. The majority of the stores is franchised store. SEJ owns small number of stores only (about $5 \%$ ). The second strategy is partnership with distribution centers. CDC dedicatedly serves 7-11 stores. However, the CDC is managed by vendors or a third party. They have achieved a mutual prosperity of the business (Fig. 4). The third strategy is outsourcing. SEJ has to manage huge networks and data processing, and that is why, it has outsourced the system development and operation to system integration companies.

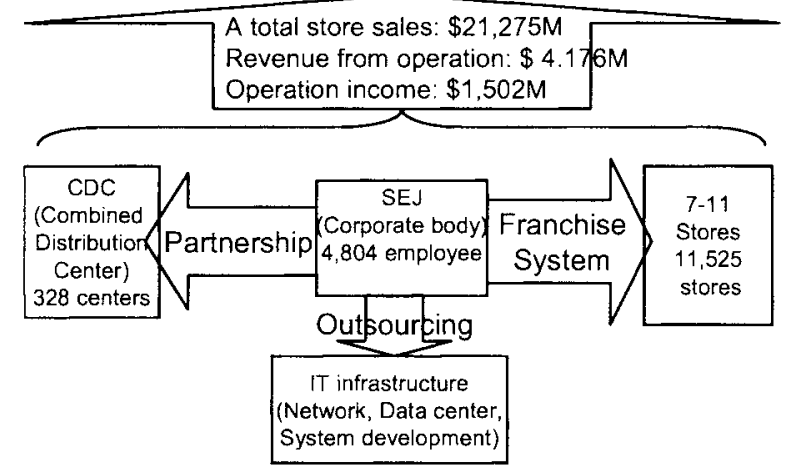

Fig. 4. Lean management in SEJ

SEJ is deeply focusing on the customer. SEJ is an excellent world retail company. SEJ doesn't intend to be a lean retail company. However, there is some unique lean management practice in its business operations. 


\section{Conclusions}

In our paper, we aim to report on the introduction of lean to retailing industry. In order to demonstrate that lean principles and concepts are successfully applied in a company from the retail industry, we presented the case of Seven-Eleven Japan. Without being a lean company, Seven-Eleven Japan have obtained high business performances.

The clear conclusion that emerges from our paper is that lean companies are able to be more responsive to market trends, deliver products faster, and provide products less expensively than their non-lean competitors.

By putting significant limits on inventory space at the store, Seven-Eleven Japan needs rapid replenishment of items. In order to deliver products in time and with minimal amount of lead times, the retailing chain has created its own distribution system, which it has integrated with all the stores. Seven-Eleven distribution centers carry no inventory. Seven-Eleven Japan has proved to be an excellent retail company.

\section{References}

[1] Liker J. K.- The Toyota way. 14 management principles from the world's greatest manufacturer, McGraw-Hill, New York, 2004

[2] Loeb A. L.- Birth of the Kettering doctrine: fordism, sloanism and the discovery of tetraethyl lead, Business and Economic History, vol. 24, no. 1, Fall 1995

[3] Fujimoto T.- The evolution of a manufacturing system at Toyota, Oxford University Press, New York, 1999

[4] Fujimoto H.- Supply Chain for the Synchronization of Production and Distribution, Osaka Keidai Ronshu, vol. 53, no.3, September 2002

[5] Harris A.- Made in the USA, Manufacturing Engineering, February 2007, http://www.itc.mb.ca/downloads (last accessed April 2007)

[6] Monden Y.- Toyota Production System: an integrated approach to just-in-time, EMP, Institute of Industrial Engineers, Norcross, 1998

[7] Ohno T.- Toyota Production System: beyond large-scale production, Productivity Press, Oregon, 1988

[8] Sakai Y., Sugano T., Maeda T.- Introduction of Toyota Production System to promote innovative manufacturing, Fujitsu Science Technology Japan, no. 43, p. 14-22, January 2007, http://www.fujitsu.com (last accessed March 2007)

[9] Shimizu K.- Le toyotisme, Editions la Decouverte, Paris, 1999

[10] Weil D.- Lean Retailing and Supply Chain Restructuring: Implications for Private and Public Governance, Paper prepared for "Observing Trade: Revealing International Trade Networks", Princeton Institute for International and Regional Studies, Princeton University, 9-11.03.2006

[12] Womack J. P., Jones D. T.- Lean thinking. Banish waste and create wealth in your corporation, The Free Press, New York, 2003

[13] Annual report 2005, Corporate outline 2005, CSR Report 2005, Corporate profile 2006, Seven-Eleven Japan Co.,Ltd, http://www.sej.co.jp (last accessed April 2007) 